\title{
Treatment Regimen \#4
}

National Cancer Institute

\section{Source}

National Cancer Institute. Treatment Regimen \#4. NCI Thesaurus. Code C159877.

The fourth treatment regimen. 